\title{
18-27 Yaş Arası Bireylerde Vücut Kütle İndeksine Göre Beslenme Alışkanlıklarının, Fiziksel Aktivitelerinin ve Vücut Kompozisyonlarının Değerlendirilmesi
}

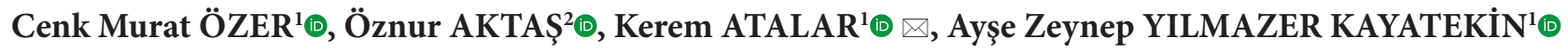 \\ ${ }^{1}$ Zonguldak Bülent Ecevit Üniversitesi, Tip Fakültesi, Anatomi Anabilim Dalı, Zonguldak \\ ${ }^{2}$ Zonguldak Bülent Ecevit Üniversitesi, Sağlık Bilimleri Enstitüsü, Anatomi Anabilim Dalı, Zonguldak \\ Bu makaleye yapılacak atıf: Özer CM, Aktaş Ö, Atalar K, Yılmazer Kayatekin Z. 18-27 Yaş Arası Bireylerde Vücut Kütle İndeksine Göre Beslenme Alışkanlıklarının, Fiziksel \\ Aktivitelerinin ve Vücut Kompozisyonlarının Değerlendirilmesi. Türk Diyab Obez 2019;1: 15-21.
}

\begin{abstract}
ÖZET
Amaç: Bu çalı̧̧mada Vücut Kütle İndeksi $25 \mathrm{~kg} / \mathrm{m}^{22}$ nin altında olan bireyler ile Vücut Kütle İndeksi $25 \mathrm{~kg} / \mathrm{m}^{23}$ in üzerinde olan bireylerin fiziksel aktivitelerinin, beslenme alışkanlıklarının ve Biyoelektrik İmpedans Analizi yöntemi kullanılarak elde edilen vücut kompozisyonlarının değerlendirilmesi amaçlandı.

Gereç ve Yöntemler: Çalışmaya, Zonguldak Bülent Ecevit Üniversitesi Tip Fakültesi, Sağlık Bilimleri Fakültesi ve Sağlık Meslek Yüksekokulu öğrencilerinden 131 (70 kadın, 61 erkek) gönüllü dahil edildi. Çalışmaya katılan öğrencilere Tanita BC 418 cihazı ile Biyoelektrik İmpedans Analizi yapılarak Vücut Kütle İndeksleri belirlendi ve elde edilen vücut kompozisyonları kaydedildi. Vücut Kütle İndeksi $25 \mathrm{~kg} / \mathrm{m}^{23}$ nin altında ve üzerinde olan iki grup oluşturuldu. Katılımcılara Demografik Bilgiler Formu, Beslenme Alışkanlıkları İndeksi, Uluslararası Fiziksel Aktivite Anketi uygulandı.

Bulgular: Vücut Kütle İndeksi $25 \mathrm{~kg} / \mathrm{m}^{23}$ nin üzerindeki erkeklerde öğün atlama, kadınlarda vitamin ve mineral kullanımı ve her iki cinsiyette de iç yağlanma, yağ yüzde oranı, gövde yağ oranı, bazal metabolizma hızı, obezite derecesi istatistiksel olarak anlamlı ölçüde yüksekti $(\mathrm{p}<0,05)$. Vücut Kütle İndeksi $25 \mathrm{~kg} / \mathrm{m}^{23}$ nin altındaki kadınlarda ise mineral miktarı; her iki cinsiyette yağsız kütle oranı, protein oranı, iskeletsel kas oranı, sıvı oranı, yağ dışı oran, kas oranı, kemik oranı istatistiksel olarak anlamlı ölçüde yüksekti $(\mathrm{p}<0,05)$. Kadın ve erkeklerde yapılan korelasyon analizinde Vücut Kütle İndeksi ile Beslenme Alışkanlıkları İndeksi arasında istatistiksel olarak anlamlı bir ilişki saptanmazken, Vücut Kütle İndeksi ile bazal metabolizma hızı arasında pozitif yönlü kuvvetli ilişki saptandı ( $<0,001$, kadınlar için $\mathrm{r}=0,898$, erkekler için $\mathrm{r}=0,842$ ).
\end{abstract}

Sonuç: Yaptığımız bu çalışmada Biyoelektiriksel İmpedans Analizi ile ölçülen bazı vücut kompozisyonu parametreleri ile Vücut Kütle İndeksi arasında anlamlı ilişki olduğu görüldü.

Anahtar Sözcïkler: Vücut kütle indeksi, Vücut kompozisyonlarl, Biyoelektriksel impedans analizi, Uluslararası fiziksel aktivite anketi, Beslenme alışkanlikları indeksi

\section{Evaluation of Nutritional Habits, Physical Activities and Body Compositions of Individuals Between Age of 18 And 27 by Their Body Mass Index}

\begin{abstract}
Aim: The aim of this study was to evaluate the physical activity, nutritional habits, and body composition calculated by Bioelectrical Impedance Analysis, of the individuals whose Body Mass Index were below $25 \mathrm{~kg} / \mathrm{m}^{2}$ and above $25 \mathrm{~kg} / \mathrm{m}^{2}$.

Material and Methods: 131 students (70 female, 61 male) of Bulent Ecevit University Medical Faculty, Health Sciences Faculty and Vocational School of Health Sciences were voluntarily involved in the study. Body Mass Index values were measured via Bioelectric Impedance Analysis by Tanita BC 418 and body composition values were saved. Students divided into two groups according to Body

ORCID: Cenk Murat Özer / 0000-0002-7813-723X, Öznur Aktaş / 0000-0002-0133-2344, Kerem Atalar / 0000-0003-1239-1144, Zeynep Yllmazer Kayatekin / 0000-0003-1144-382X


Mass Index values as below and above $25 \mathrm{~kg} / \mathrm{m}^{2}$. Demographic Information Form, Nutrition Habits Index and International Physical Activity Questionnaire applied to all volunteers on both groups.

Results: In the group with a Body Mass Index of more than $25 \mathrm{~kg} / \mathrm{m}^{2}$, visceral fat, fat percentage ratio, core fat content, basal metabolic rate and obesity level were significantly higher, meal skipping was higher in males only, and both vitamin and mineral use were higher in females only $(\mathrm{p}<0.05)$. In the group with Body Mass Index less than $25 \mathrm{~kg} / \mathrm{m}^{2}$, the rate of lean mass, protein content ratio, skelatal muscle ratio, body water ratio, lean tissue ratio, muscle ratio and bone ratio were found to be significantly higher and the mineral content was higher in females only $(\mathrm{p}<0.05)$. There was no statistically significant relationship between Body Mass Index and Nutrition Habits Index in male and female correlation analysis, but a positive and high correlation was found between Body Mass Index and basal metabolic rate $(\mathrm{p}<0.001$; for females $\mathrm{r}=0.848$, for males $\mathrm{r}=0.842)$.

Conclusion: In our study, a significant correlation between Body Mass Index and some body composition parameters measured by Bioelectrical Impedance Analysis was found.

Key Words: Body mass index, Body compositions, Bioelectric impedance analysis, Nutritional habits index, International physical activity questionnaire

\section{GİRIŞ ve AMAÇ}

Dünya Sağlik Örgütü (DSÖ) obeziteyi, vücuttaki yağ miktarının sağlığı olumsuz düzeyde etkileyecek kadar artışı olarak tanımlamıştır. Bilinenin aksine obezite, kilo fazlalı̆̆ 1 değil vücuttaki yağ oranının normalden fazla olmasıdır (1). Obezite, dünyada görülme sıklığ giderek artan bir sağlık sorunudur ve Türkiye'de de obezite prevalansı son 20 yıl içerisinde 3 kat artmıştır $(1,2)$.

Obezite etiyolojisi tam olarak bilinmeyen multifaktöriyel bir hastalık olarak düşünülmektedir. Oluşumunda genetik, çevresel, sosyal, psikolojik, metabolik ve hormonal faktörler ile sedanter yaşam tarzı, beslenme alışkanlıkları, sosyoekonomik nedenler rol oynamaktadır (3). Fiziksel aktivitedeki azalma, dengesiz ve düzensiz beslenme alışkanlıkları, sigarayı bırakma, alkol kullanımı gibi birçok faktör obezite riskini arttırmaktadır (4).

Vücut kompozisyonu, fiziksel uygunluk parametrelerinden biridir. Vücut kompozisyonunun belirlenmesi klinik sağlık ve kilo kontrolünde önemli bir faktördür. Bu parametrenin doğru olarak değerlendirilebilmesi için boy-kilo ilişkisinin yanı sıra vücut yağ yüzdesinin bilinmesi gereklidir (5). Vücut yağ yüzdesinin miktarı ve dağılımı toplam vücut ağırlığından çok daha önemlidir (3).

Vücut Kütle İndeksi (VKİ), kişinin vücut ağırlığının boyunun karesine oranı ile hesaplanır. VKİ sağlıklı yetişkinlerde vücut yağ oranının değerlendirilmesinde iyi bir ölçü kabul edildiği halde, gençlerde uygun bir ölçü olmadığ 1 belirtilmiştir. Biyoelektriksel İmpedans Analizi (BİA)'nin vücut yağını ölçtüğü ve bu yüzden özellikle sedanter gençlerde obezite tanısı için VKİ' ye göre daha doğru olduğu gösterilmiştir (5). BİA'nın çalışmasındaki temel prensip, verilen çok düşük miktardaki elektrik akımının dokudan geçerken karşılaştığ olan iletkenliğin kullanılarak impedansın ölçülmesidir.
BİA yöntemi uygulama rahatlığı, tekrarlanabilir olması, hızlı sonuç vermesi, girişimsel olmaması nedeniyle vücut kompozisyonlarının değerlendirilmesinde kullanılan en etkin yöntemler arasındadır (6).

Vücut kompozisyonu, beslenme alışkanlığı ve fiziksel aktivite arasındaki ilişkiyi göstermektedir (5). Bireyin fizyolojik ihtiyaçlarını gerçekleştirebilmesi için gerekli en düşük enerji miktarına Bazal Metabolizma Hızı (BMH) denir (7). Düzenli olarak yapılan fiziksel aktivite; kemik yoğunluğunu, bazal metabolizma hızını ve yağsız doku kütlesini artırırken vücut yağ miktarını azaltır ve böylece obezite gelişimini engeller (8). Düzensiz ve dengesiz beslenme ise vücut yağ oranının değişmesine sebep olur. Yağ bakımından zengin yiyeceklerin tüketilmesi ve hazır yiyecekler ile beslenme sıklığındaki artış sonucunda obezite ve yeme bozuklukları oranı artmaktadır (9-11).

$\mathrm{Bu}$ çalışmada Vücut Kütle İndeksi $25 \mathrm{~kg} / \mathrm{m}^{2}$ 'nin altında olan bireyler ile Vücut Kütle İndeksi $25 \mathrm{~kg} / \mathrm{m}^{2}$ in üzerinde olan bireylerin fiziksel aktivitelerinin, beslenme alışkanlıklarının ve BİA yöntemi kullanılarak elde edilen vücut kompozisyonlarının değerlendirilmesi amaçlandı.

\section{GEREÇ ve YÖNTEMLER}

$\mathrm{Bu}$ çalışma, Zonguldak Bülent Ecevit Üniversitesi Tip Fakültesi, Sağlık Bilimleri Fakültesi ve Sağlık Meslek Yüksekokulu'nda eğitim alan, yaşları 18-27 arasında değişen gönüllü 61 erkek ve 70 kadın öğrenci ile yürütüldü. Çalışmamızın etik onayı Zonguldak Bülent Ecevit Üniversitesi Klinik Araştırmalar Etik Kurulu tarafından verilmiştir (2018/22). Araştırma hakkında bilgi verildikten sonra araştırmaya katılmayı kabul eden, sistemik hastalık tanısı almamış, herhangi bir sağlık şikayeti bulunmayan, 18 yaş üstü öğrencilerden gönüllü onam formunu imzalayanlar çalışmaya dahil edildi. BİA öncesinde, öğrencilerin en az 4 saat aç kalmaları, son bir hafta içerisinde alkol tüketme- 
meleri, kadın öğrencilerden ise menstruasyon dönemi dışında ölçüm yaptırmaları istendi. Ölçümler Tanita BC 418 cihazı ile yapıldı. Ölçüm yapılırken üzerlerinde en az kıyafetle ve metal eşya bulundurmaksızın tartı cihazına çıkmaları sağlandı. Tartı cihazına çıkan öğrencilerden cihaza ait olan probları tutmaları ve dik pozisyonda karşıya bakmaları istendi. Ölçüm sonrasında VKİ belirlendi ve BİA sonucu elde edilen vücut kompozisyonları kaydedildi. VKİ'si $25 \mathrm{~kg} / \mathrm{m}^{2}$ nin altında ve üzerinde olan iki grup oluşturuldu. Ölçüm yapılan öğrencilere 12 sorudan oluşan Demografik Bilgiler Formu, Beslenme Alışkanlıkları İndeksi (BAI), Uluslararası Fiziksel Aktivite Anketi (UFAA) uygulandı.

UFAA kısa formu yedi sorudan oluşmaktadır ve son bir haftada oturma, yürüme, orta ve şiddetli aktivitelerde harcanan zamanın ve harcanan metabolik eşdeğer dakikanın (MET) değerlendirilmesine olanak sağlar (12).

BAİ, Demirezen tarafından geliştirilen, obeziteye yönelik riskli davranışların değerlendirilmesinde kullanılan anket formudur (11).

Çalışmanın istatistiksel analizleri SPSS 19 programında yapıldı. Çalışmada yer alacak sürekli değişkenlere ait tanımlayıcı istatistikler ortalama, standart sapma, medyan, minimum ve maksimum değerleriyle; kategorik değişkenler frekans ve yüzde ile gösterildi. Sürekli değişkenlerin normal dağılıma uygunluğu Shapiro Wilk testi ile incelendi. Bağımlı değişkenler arası ilişkiler Wilcoxon ve bağımlı örneklem $t$ testi ile incelendi. Sürekli değişkenlerin gruplar arası karşılaştırmalarında Mann Whitney U ve bağımsız örneklem $\mathrm{t}$ testleri kullanıldı. Çalışmadaki tüm istatistiksel analizlerde $\mathrm{p}$ değeri 0,05 'in altındaki sonuçlar istatistiksel olarak anlamlı kabul edildi.

\section{BULGULAR}

Çalışmaya katılan 131 öğrencinin 68'inin $(\% 51,9)$ VKİ’si $25 \mathrm{~kg} / \mathrm{m}^{2}$ nin altında, 63'ünün $(\% 48,1)$ VKİ'si $25 \mathrm{~kg} /$ $\mathrm{m}^{23}$ nin üzerinde olarak belirlendi. Erkeklerin \%50,8'inin, kadınların ise \%45,7'sinin VKİ'si $25 \mathrm{~kg} / \mathrm{m}^{2}$ 'nin üzerindeydi. 61 erkek öğrencinin yaş ortalamaları 20,41 $\pm 2,00,70$ kadın

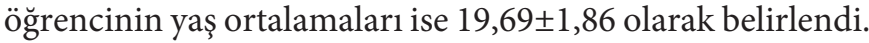

Demografik bilgiler formunda yer alan 'sigara kullanımı', 'alkol tüketimi', 'kiminle kalıyor', 'diyet uygulama' ve 'gece yemek yeme' sorularına verilen yanıtlar için kadın ve erkeklerde VKİ'si $25 \mathrm{~kg} / \mathrm{m}^{2}$ nin altındaki ve üzerindeki iki grupta da istatistiksel olarak anlamlı fark bulunamadı ( $p>0,05)$. Aynı formda yer alan 'öğün atlama' sorusuna VKİ’si $25 \mathrm{~kg} / \mathrm{m}^{23}$ nin üzerinde olan erkeklerin \%80,6'sının 'evet' yanıtını verdiği ve VKİ'si $25 \mathrm{~kg} / \mathrm{m}^{2}$ 'nin altında olan erkeklere göre istatistiksel olarak anlamlı fark gösterdiği belirlendi $(p=0,025)$. Yine aynı formda yer alan 'vitamin ve mineral kullanımı' sorusuna ise VKI'si $25 \mathrm{~kg} / \mathrm{m}^{23} \mathrm{nin}$ altındaki kadınların \%28,1'i 'evet' yanıtını verdiği ve VKİ'si $25 \mathrm{~kg} / \mathrm{m}^{2}$ nin üzerinde olan kadınlara göre istatistiksel olarak anlamlı fark gösterdiği belirlendi $(\mathrm{p}=0,004)$.

Beslenme Alışkanlıkları İndeksi sonuçlarına göre VKİ'si $25 \mathrm{~kg} / \mathrm{m}^{2}$ 'nin altındaki kadın ve erkeklerde; yağsız kütle oranı, yumuşak kas dokusu oranı, iskeletsel kas ağırlığı oranı, protein miktarı oranı, sıvı ağırlığı oranı, kas ağırlığ oranı, kemik mineralleri ağırlığı oranı, hücre içi ve dışı sıvı ağırlığı oranı, hücre kütlesi oranı, yağ dışı ağırlık oranı, sağ ve sol bacak kas ağırlığ oranı, gövde kas ağırlı̆̆ oranı VKİ’si $25 \mathrm{~kg} / \mathrm{m}^{23}$ nin üzerinde olanlardan daha düşük olarak belirlendi ve fark istatistiksel olarak anlamlıydı $(\mathrm{p}<0,05)$. VKİ'si $25 \mathrm{~kg} / \mathrm{m}^{23}$ nin üzerindeki kadın ve erkeklerde; iç yağlanma, yağ ağırlığı oranı, sağ ve sol bacak yağ ağırlığı oranı, sağ ve sol kol yağ ağırlığı oranı, gövde yağ ağırlı̆̆ı oranı, bazal metabolizma hızı VKİ'si 25 $\mathrm{kg} / \mathrm{m}^{2}$ nin altında olanlardan yüksek olarak belirlendi ve fark istatistiksel olarak anlamlıydı $(\mathrm{p}<0,05)$. VKİ’si $25 \mathrm{~kg} /$ $\mathrm{m}^{2}$ 'nin altında olan kadınlarda mineral miktarı oranı ve beden yoğunluğu VKİ’si $25 \mathrm{~kg} / \mathrm{m}^{23}$ nin üzerinde olanlardan daha yüksek olarak belirlendi ve aralarında istatistiksel olarak anlamlı fark görüldü $(\mathrm{p}<0,05)$ (Tablo 1$)$.

Kadın ve erkeklerde VKİ, UFAA, BAİ ve BMH arasinda yapilan korelasyon analizi sonucunda VKİ ile BAİ ve UFAA arasında istatistiksel olarak anlamlı bir ilişki saptanmadı (p>0,05). VKİ ile BMH arasında pozitif yönlü kuvvetli ilişki $\operatorname{vard}_{1}$ (her ikisi için $\mathrm{p}<0,001$, kadınlar için $\mathrm{r}=0,898$, erkekler için $\mathrm{r}=0,842$ ) (Tablo 2).

Erkeklerde yapilan korelasyon analizinde obezite derecesi ile yağsız kütle oranı, protein oranı ve beden yoğunluğu arasında negatif yönlü kuvvetli ilişki varken iç yağlanma ile arasında pozitif yönlü kuvvetli ilişki vardı (Tablo 3). Kadınlarda yapılan korelasyon analizinde obezite derecesi ile yağsız kütle oranı, protein oranı, mineral miktarı oranı ve beden yoğunluğu arasında negatif yönlü kuvvetli ilişki varken iç yağlanma ile arasında pozitif yönlü kuvvetli ilişki vardı (Tablo 4). Kadın ve erkeklerde ayrı ayrı yapılan korelasyon analizinde yağsız kütle oranı ile protein miktarı oranı ve beden yoğunluğu arasında pozitif yönlü kuvvetli ilişki, mineral miktarı oranı ile pozitif yönlü orta kuvvette ilişki, iç yağlanma ile negatif yönlü kuvvetli ilişki görüldü. Mineral miktarı oranı ile iç yağlanma arasında negatif yönlü düşük kuvvette, beden yoğunluğu ile arasında ise pozitif yönlü orta kuvvette ilişki vardı. Protein miktarı oranı ile iç yağlanma arasında yapılan değerlendirmede negatif yönlü kuvvetli ilişki, beden yoğunluğu ile arasında yapılan değerlendirmede ise pozitif yönlü kuvvetli ilişki görüldü. İç yağlanma ile beden yoğunluğu arasında negatif yönlü kuvvetli ilișki vardı (Tablo 3 ve 4 ). Kadın ve erkeklerde 
Tablo 1. BİA ile elde edilen vücut kompozisyonlarının VKİye ve cinsiyete göre değerlendirilmesi.

\begin{tabular}{|c|c|c|c|c|c|c|}
\hline & \multicolumn{3}{|c|}{ Kadın } & \multicolumn{3}{|c|}{ Erkek } \\
\hline & $\mathrm{VK} \dot{\mathrm{I}}<25 \mathrm{~kg} / \mathrm{m}^{2}$ & VKİ $>25 \mathrm{~kg} / \mathrm{m}^{2}$ & $\mathbf{p}$ & $\mathrm{VK} \dot{\mathrm{I}}<25 \mathrm{~kg} / \mathrm{m}^{2}$ & $\mathrm{VKI}>25 \mathrm{~kg} / \mathrm{m}^{2}$ & $\mathbf{p}$ \\
\hline Yağsız kütle oranı $(\% \pm S S)$ & $75,90 \pm 5,96$ & $61,48 \pm 4,72$ & $<0,001$ & $85,13 \pm 4,45$ & $76,91 \pm 5,28$ & $<0,001$ \\
\hline Mineral oranı $(\% \pm S S)$ & $4,30 \pm 0,57$ & $3,80 \pm 0,75$ & 0,004 & $5,31 \pm 0,95$ & $5,05 \pm 0,924$ & 0,275 \\
\hline Protein oranı $(\% \pm S S)$ & $16,02 \pm 1,68$ & $12,66 \pm 1,08$ & $<0,001$ & $17,48 \pm 1,29$ & $15,55 \pm 1,59$ & $<0,001$ \\
\hline İç yağlanma & $1,31 \pm 0,52$ & $5,28 \pm 2,20$ & $<0,001$ & $1,93 \pm 1,01$ & $6,25 \pm 2,75$ & $<0,001$ \\
\hline Beden yoğunluğu & $1,04 \pm 0,01$ & $1,00 \pm 0,01$ & $<0,001$ & $1,06 \pm 0,11$ & $1,058 \pm 0,07$ & 0,636 \\
\hline Yumuşak kas oranı $(\% \pm S S)$ & $71,60 \pm 5,96$ & $57,67 \pm 4,37$ & $<0,001$ & $79,83 \pm 4,26$ & $71,85 \pm 4,81$ & $<0,001$ \\
\hline İskeletsel kas oranı $(\% \pm S S)$ & $42,96 \pm 3,37$ & $34,79 \pm 2,67$ & $<0,001$ & $48,18 \pm 2,51$ & $43,53 \pm 2,99$ & $<0,001$ \\
\hline Hücre dışı sıvı oranı $(\% \pm S S)$ & $23,51 \pm 1,83$ & $19,04 \pm 1,47$ & $<0,001$ & $26,37 \pm 1,37$ & $23,81 \pm 1,63$ & $<0,001$ \\
\hline Hücre içi sıvı oranı $(\% \pm S S)$ & $32,06 \pm 2,52$ & $25,96 \pm 1,99$ & $<0,001$ & $35,95 \pm 1,88$ & $32,48 \pm 2,23$ & $<0,001$ \\
\hline Hücre kütle oranı $(\% \pm S S)$ & $48,56 \pm 3,81$ & $39,33 \pm 3,06$ & $<0,001$ & $55,02 \pm 2,90$ & $49,58 \pm 3,40$ & $<0,001$ \\
\hline Yağ yüzde oranı $(\% \pm S S)$ & $14,87 \pm 4,45$ & $23,10 \pm 5,28$ & $<0,001$ & $14,87 \pm 4,45$ & $23,10 \pm 5,28$ & $<0,001$ \\
\hline Siv1 oranı $(\% \pm S S)$ & $55,57 \pm 4,35$ & $45,09 \pm 3,46$ & $<0,001$ & $62,33 \pm 3,25$ & $56,29 \pm 3,87$ & $<0,001$ \\
\hline Yağ dışı oranı $(\% \pm S S)$ & $75,90 \pm 5,96$ & $61,48 \pm 4,72$ & $<0,001$ & $85,13 \pm 4,45$ & $76,91 \pm 5,28$ & $<0,001$ \\
\hline Kas oranı $(\% \pm S S)$ & $72,08 \pm 5,64$ & $58,37 \pm 4,53$ & $<0,001$ & $81,39 \pm 4,28$ & $73,40 \pm 5,04$ & $<0,001$ \\
\hline Kemik oranı $(\% \pm S S)$ & $3,82 \pm 0,38$ & $3,10 \pm 0,21$ & $<0,001$ & $3,74 \pm 0,21$ & $3,50 \pm 0,25$ & $<0,001$ \\
\hline Bacak kas oranı $(\% \pm S S)$ & $24,45 \pm 1,99$ & $20,08 \pm 1,26$ & $<0,001$ & $27,5 \pm 2,24$ & $25,47 \pm 1,37$ & $<0,001$ \\
\hline Kol kas oranı $(\% \pm S S)$ & $6,44 \pm 0,57$ & $5,67 \pm 0,37$ & $<0,001$ & $8,5 \pm 0,28$ & $8,03 \pm 1,01$ & 0,033 \\
\hline Gövde kas oranı $(\% \pm S S)$ & $41,14 \pm 3,41$ & $32,63 \pm 3,02$ & $<0,001$ & $45,22 \pm 2,86$ & $39,75 \pm 3,39$ & $<0,001$ \\
\hline Bacak yağ oranı $(\% \pm S S)$ & $11,01 \pm 1,60$ & $14,49 \pm 1,10$ & $<0,001$ & $4,60 \pm 1,51$ & $7,41 \pm 2,17$ & $<0,001$ \\
\hline Kol yağ oranı $(\% \pm S S)$ & $2,41 \pm 0,65$ & $4,48 \pm 0,93$ & $<0,001$ & $1,86 \pm 0,46$ & $2,70 \pm 0,58$ & $<0,001$ \\
\hline Gövde yağ oranı $(\% \pm S S)$ & $10,77 \pm 3,96$ & $19,53 \pm 3,20$ & $<0,001$ & $8,41 \pm 2,83$ & $13,01 \pm 3,15$ & $<0,001$ \\
\hline $\mathrm{BMH}$ & $1305,76 \pm 101,28$ & $1558,28 \pm 153,55$ & $<0,001$ & $1695,90 \pm 199,91$ & $2151,35 \pm 265,69$ & $<0,001$ \\
\hline Obezite derecesi & $-4,28 \pm 11,68$ & $39,44 \pm 18,85$ & $<0,001$ & $2,34 \pm 12,28$ & $39,07 \pm 12,90$ & $<0,001$ \\
\hline
\end{tabular}

\#Mann Whitney U testi.

Tablo 2. VKİ ile BMH, UFAA ve BAİ arasındaki korelasyon analizi.

\begin{tabular}{cccccccc}
\hline & \multicolumn{3}{c}{ Kadın } & & \multicolumn{3}{c}{ Erkek } \\
\cline { 2 - 8 } & & BMH & BAİ & UFAA & BMH & BAİ & UFAA \\
\hline \multirow{2}{*}{ VKİ } & $\mathrm{r}$ & 0,898 & 0,108 & $-0,168$ & 0,842 & $-0,51$ & 0,102 \\
\cline { 2 - 8 } & $\mathrm{p}$ & $<0,001$ & 0,373 & 0,164 & $<0,001$ & 0,698 & 0,435 \\
\hline
\end{tabular}

\#Spearman Rho korelasyon analizi.

beraber yapılan korelasyon analizinde mineral miktarı oranı ile iç yağlanma arasında istatistiksel olarak anlamlı bir ilişki bulunmazken, protein miktarı oranı ile pozitif düşük şiddette ilişki vardı (Tablo 5).

Kadın ve erkeklerde BAİ formunda bulunan yağlı ve şekerli yiyecekler tüketme; yiyeceklere tuz ekleme; kahve, çay, kola vb içecekleri tüketme; hazır gıda tüketme; kırmızı et tüketme ve lifli yiyecekler tüketme sıklı̆̆ının VKİ ile anlamlı bir ilişkisi yoktu ( $>>0,05)$. Kadın ve erkeklerde, tuz kullanımı sıklığının sıvı ağırlığı oranı ile anlamlı bir ilişkisi yoktu (kadınlar için $\mathrm{p}=0,648$ erkekler için $\mathrm{p}=0,093$ ).

\section{TARTIŞMA}

Obezite, sık görülen halk sağlığı sorunlarından biridir. VKİ, obezitenin tanıve takibi için kullanılan, Dünya Sağlık Örgütü tarafından önerilen kolay ve etkili bir yöntemdir $(1,5)$. Fakat yapılan çalışmalarda genç ve çocuklarda VKİnin uygun bir 
Tablo 3. Erkeklerde, BİA ile elde edilen vücut kompozisyonlarının korelasyonu.

\begin{tabular}{|c|c|c|c|c|c|c|}
\hline Erkeklerde $(n=61)$ & $\begin{array}{l}\text { Obezite } \\
\text { Derecesi }\end{array}$ & $\begin{array}{c}\text { Yağsız Kütle } \\
\text { Oranı }\end{array}$ & $\begin{array}{c}\text { Mineral } \\
\text { Miktarı Oranı }\end{array}$ & $\begin{array}{c}\text { Protein } \\
\text { Oranı }\end{array}$ & İç Yağlanma & $\begin{array}{c}\text { Beden } \\
\text { Yoğunluğu }\end{array}$ \\
\hline Obezite Derecesi & - & & & & & \\
\hline Yağsız Kütle Oranı & $\begin{array}{l}\mathrm{r}=-0,802 \\
\mathrm{p}<0,001\end{array}$ & - & & & & \\
\hline Mineral Miktarı Oranı & $\begin{array}{l}r=-0,224 \\
p=0,082\end{array}$ & $\begin{array}{l}r=0,461 \\
p<0,001\end{array}$ & - & & & \\
\hline Protein Oranı & $\begin{array}{l}\mathrm{r}=-0,766 \\
\mathrm{p}<0,001\end{array}$ & $\begin{array}{l}\mathrm{r}=0,836 \\
\mathrm{p}<0,001\end{array}$ & $\begin{array}{l}r=-0,063 \\
p=0,012\end{array}$ & - & & \\
\hline İç Yağlanma & $\begin{array}{l}\mathrm{r}=0,923 \\
\mathrm{p}<0,001\end{array}$ & $\begin{array}{l}=-0,937 \\
p<0,001\end{array}$ & $\begin{array}{l}\mathrm{r}=-0,320 \\
\mathrm{p}=0,012\end{array}$ & $\begin{array}{l}r=-0,859 \\
p<0,001\end{array}$ & - & \\
\hline Beden Yoğunluğu & $\begin{array}{l}r=-0,766 \\
p<0,001\end{array}$ & $\begin{array}{l}\mathrm{r}=0,949 \\
\mathrm{p}<0,001\end{array}$ & $\begin{array}{l}\mathrm{r}=0,476 \\
\mathrm{p}<0,001\end{array}$ & $\begin{array}{l}\mathrm{r}=0,774 \\
\mathrm{p}<0,001\end{array}$ & $\begin{array}{l}=-0,888 \\
p<0,001\end{array}$ & - \\
\hline
\end{tabular}

\#Spearman Rho korelasyon analizi.

Tablo 4. Kadınlarda, BİA ile elde edilen vücut kompozisyonlarının korelasyon analizi.

\begin{tabular}{|c|c|c|c|c|c|c|}
\hline $\begin{array}{l}\text { Kadınlarda } \\
(n=70)\end{array}$ & $\begin{array}{l}\text { Obezite } \\
\text { Derecesi }\end{array}$ & $\begin{array}{c}\text { Yağsız Kütle } \\
\text { Oranı }\end{array}$ & $\begin{array}{c}\text { Mineral } \\
\text { Miktarı Oranı }\end{array}$ & $\begin{array}{c}\text { Protein } \\
\text { Oranı }\end{array}$ & $\begin{array}{c}\text { İç } \\
\text { Yağlanma }\end{array}$ & $\begin{array}{l}\text { Beden } \\
\text { Yoğunluğu }\end{array}$ \\
\hline Obezite Derecesi & - & & & & & \\
\hline Yağsız Kütle Oranı & $\begin{array}{l}\mathrm{r}=-0,959 \\
\mathrm{p}<0,001\end{array}$ & - & & & & \\
\hline Mineral Miktarı Oranı & $\begin{array}{l}\mathrm{r}=-0,417 \\
\mathrm{p}<0,001\end{array}$ & $\begin{array}{l}\mathrm{r}=0,447 \\
\mathrm{p}<0,001\end{array}$ & - & & & \\
\hline Protein Oranı & $\begin{array}{l}=-0,907 \\
p<0,001\end{array}$ & $\begin{array}{l}\mathrm{r}=0,944 \\
\mathrm{p}<0,001\end{array}$ & $\begin{array}{l}\mathrm{r}=-0,143 \\
\mathrm{p}=0,236\end{array}$ & - & & \\
\hline İç Yağlanma & $\begin{array}{l}\mathrm{r}=0,953 \\
\mathrm{p}<0,001\end{array}$ & $\begin{array}{c}r=-0,958 \\
p<0,001\end{array}$ & $\begin{array}{c}\mathrm{r}=-0,367 \\
\mathrm{p}=0,02\end{array}$ & $\begin{array}{l}\mathrm{r}=-0,922 \\
\mathrm{p}<0,001\end{array}$ & - & \\
\hline Beden Yoğunluğu & $\begin{array}{l}\mathrm{r}=-0,959 \\
\mathrm{p}<0,001\end{array}$ & $\begin{array}{l}\mathrm{r}=1,000 \\
\mathrm{p}<0,001\end{array}$ & $\begin{array}{l}\mathrm{r}=0,443 \\
\mathrm{p}<0,001\end{array}$ & $\begin{array}{l}\mathrm{r}=0,945 \\
\mathrm{p}<0,001\end{array}$ & $\begin{array}{l}\mathrm{r}=-0,959 \\
\mathrm{p}<0,001\end{array}$ & - \\
\hline
\end{tabular}

\#Spearman Rho korelasyon analizi.

Tablo 5. Kadın ve erkeklerde, BİA ile elde edilen vücut kompozisyonlarının korelasyon analizi.

\begin{tabular}{|c|c|c|c|c|c|c|}
\hline $\begin{array}{l}\text { Kadın ve Erkeklerde } \\
(n=131)\end{array}$ & $\begin{array}{l}\text { Obezite } \\
\text { Derecesi }\end{array}$ & $\begin{array}{c}\text { Yağsız Kütle } \\
\text { Oranı }\end{array}$ & $\begin{array}{c}\text { Mineral } \\
\text { Miktarı Oranı }\end{array}$ & $\begin{array}{c}\text { Protein } \\
\text { Oranı }\end{array}$ & $\begin{array}{c}\text { İç } \\
\text { Yağlanma }\end{array}$ & $\begin{array}{c}\text { Beden } \\
\text { Yoğunluğu }\end{array}$ \\
\hline Obezite Derecesi & - & & & & & \\
\hline Yağsız Kütle Oranı & $\begin{array}{l}\mathrm{r}=-0,608 \\
\mathrm{p}<0,001\end{array}$ & - & & & & \\
\hline Mineral Miktarı Oranı & $\begin{array}{l}\mathrm{r}=-0,173 \\
\mathrm{p}=0,048\end{array}$ & $\begin{array}{l}\mathrm{r}=0,581 \\
\mathrm{p}<0,001\end{array}$ & - & & & \\
\hline Protein Oranı & $\begin{array}{l}r=-0,679 \\
p<0,001\end{array}$ & $\begin{array}{l}\mathrm{r}=0,926 \\
\mathrm{p}<0,001\end{array}$ & $\begin{array}{l}\mathrm{r}=-0,253 \\
\mathrm{p}=0,004\end{array}$ & - & & \\
\hline İç Yağlanma & $\begin{array}{l}\mathrm{r}=0,943 \\
\mathrm{p}<0,001\end{array}$ & $\begin{array}{l}\mathrm{r}=-0,586 \\
\mathrm{p}<0,001\end{array}$ & $\begin{array}{l}\mathrm{r}=-0,138 \\
\mathrm{p}=0,115\end{array}$ & $\begin{array}{l}\mathrm{r}=-0,659 \\
\mathrm{p}<0,001\end{array}$ & - & \\
\hline Beden Yoğunluğu & $\begin{array}{l}\mathrm{r}=-0,594 \\
\mathrm{p}<0,001\end{array}$ & $\begin{array}{l}\mathrm{r}=0,991 \\
\mathrm{p}<0,001\end{array}$ & $\begin{array}{l}\mathrm{r}=0,589 \\
\mathrm{p}<0,001\end{array}$ & $\begin{array}{l}\mathrm{r}=0,913 \\
\mathrm{p}<0,001\end{array}$ & $\begin{array}{l}\mathrm{r}=-0,569 \\
\mathrm{p}<0,001\end{array}$ & - \\
\hline
\end{tabular}

\#Spearman Rho korelasyon analizi. 
ölçüt olmadığı, özellikle sedanter gençlerde vücut yağının değerlendirilmesinde BİA'nın VKİ'ye göre daha etkili ve doğru olduğu belirtilmiştir (5). Kaya ve ark. 2009 yllında yaşları 14-23 arasında değişen 714 erkek ve 439 kadın denek üzerinde yaptığı çalışmada VKİ ile BİA değerleri arasında istatistiksel olarak anlamlı fark belirlemiş ve VKİ'nin kemik ile kas yapısından etkilenip özellikle büyüme döneminde yağ değişimi hakkında doğru bilgi veremeyeceğini bildirmiştir (3).

Vücutta yağ miktarı arttıkça su ve kas miktarı oranları azalmaktadır (6). Ayvaz ve ark. 2009 yilında $32 \mathrm{obez}$ (yaş ortalaması 12,63 $\pm 2,35$ ) ve 32 normal kiloda (yaş ortalaması $13,59 \pm 2,09$ ) toplam 64 çocuk üzerinde yaptığ ç̧alışmada obez grupta vücut su miktarı yüzdesinin daha düşük olduğunu bulmuştur (13). Bizim çalışmamız da bunu destekleyecek niteliktedir ve her iki cinsiyette yapılan analizlerde VKİ'si $25 \mathrm{~kg} / \mathrm{m}^{2}$ nin altındaki öğrencilerde su miktarı oranı, hücre içi sıvı oranı, hücre dışı sıvı oranı ve kas oranı VKİ’si 25 kg/ $\mathrm{m}^{2}$ nin üzerinde olan öğrencilere göre istatistiksel olarak anlamlı şekilde daha yüksekti.

Obezitenin oluşumunda fiziksel aktivite ve beslenme alışkanlıkları önemli bir yere sahiptir $(1,6,14)$. Savcı ve ark. 2006 yılında yaşları 18-32 arasında değişen 721 kadın 376 erkek öğrenci üzerinde yaptıkları çalışmada VKİ'si $25 \mathrm{~kg} / \mathrm{m}^{23}$ nin altında olan erkek öğrencilerin kadın öğrencilere göre daha fazla fiziksel aktivite puanına sahip oldukları belirtilmiştir (12). Aktaş ve ark. 2016 yılında yaş ortalamaları 20,87 olan 260 öğrenci ile yapmış oldukları çalışmada BAİ ile VKİ arasında zayıf şiddette negatif ilişki olduğunu saptamışlardır (15). Bizim çalışmamızda yapılan korelasyon analizi sonucu VKİ ile UFAA ve BAİ arasında istatistiksel olarak anlamlı bir ilişki yoktu. Bunun sebebi çalışma grubumuzun yaş ortalamasının farklı olması ve öğrenci sayısının daha düşük olmasından kaynaklanıyor olabilir.

BMH yağ, kas kütlesi ve iç organların büyüklüğünden etkilenir (16). Temur'un 2018 yilında yaşları 8 ile 13 arasında değişen 66 kadın 32 erkek öğrenci üzerinde yaptıkları çalışmada vücut ağırlı̆̆ı arttıkça BMH'nin de arttığını belirtmişlerdir (16). Biz de benzer şekilde VKİ ile BMH arasında pozitif yönlü kuvvetli ilişki bulduk.

Tuz, vücuttaki sıvi-elektrolit dengesinin düzenlenmesinde rol alır $(17,18)$. Ancak yaptığımız çalışmada her iki cinsiyette de BAİ formunda yer alan tuz kullanım sıklığı ile sıvı oranı arasında anlamlı korelasyon belirlenemedi.

Literatürde, obezitenin osteoporoz üzerine olumlu ve olumsuz etkisi hakkında farklı görüşler vardır $(19,20)$. VKİ'nin her bir birimlik artışının osteoporoza neden olan değiştirilebilir risk faktörlerinden (sigara, fiziksel aktivite, fonksiyonel kapasite, kalsiyum alımı) en çok kemik mineral yoğunluğunu etkilediği belirtilmiştir (21). Asomaning ve ark. 2006 yılında yaşları 50 ile 84 arasında değişen 1769 kadın üzerinde yaptığı çalışmada VKİsi normale göre düşük olan kadınlarda osteoporoz riskinin arttığını belirtmiştir (21). Bizim çalışmamızda, VKİ’si $25 \mathrm{~kg} / \mathrm{m}^{2}$ den düşük olan kadın öğrencilerde kemik mineral ağırlığı oranı ve mineral miktarı oranı VKİ'si $25 \mathrm{~kg} / \mathrm{m}^{2}$ den yüksek olan kadın öğrencilere göre istatistiksel olarak anlamlı şekilde daha fazlaydı. Bunun sebebi çalışma grubumuzun genç olmasından kaynaklanıyor olabilir. VKİ ile osteoporoz arasındaki ilişkinin çok daha iyi anlaşılabilmesi için VKİ'si yüksek bireylerin, gençlik döneminden itibaren uzun süreli takibinin yapılmasının yararlı olacağı düşünülebilir.

VKİsi $25 \mathrm{~kg} / \mathrm{m}^{2}$ nin altında olan öğrencilerin protein miktarı oranları VKİ'si $25 \mathrm{~kg} / \mathrm{m}^{2}$ 'nin üzerinde olan öğrencilere göre istatistiksel olarak anlamlı şekilde daha yüksekti. Elde edilen bu sonucun, VKİ'si düşük olan grupta aynı zamanda iskeletsel kas oranı ve yumuşak kas oranının yüksek olmasından kaynaklandığı düşünülebilir.

\section{SONUÇ}

Yapmış olduğumuz bu çalışmada VKİ'si $25 \mathrm{~kg} / \mathrm{m}^{2}$ 'nin altında olan bireyler ile Vücut Kütle İndeksi $25 \mathrm{~kg} / \mathrm{m}^{2}$ in üzerinde olan bireylerin fiziksel aktivitelerinin, beslenme alışkanlıklarının ve BİA yöntemi kullanılarak elde edilen vücut kompozisyonları değerlendirildi. Elde ettiğimiz sonuçlar, VKİ'ye göre vücut kompozisyonlarında belirgin farklılıklar olduğunu gösterdi. Kadın ve erkek ayrı ayrı değerlendirildiğinde bazı parametrelerin cinsiyettten etkilendiği görüldü.

\section{TEŞEKKÜR}

Çalışmamızın istatistiksel analizini yapmamızda bize yardımcı olan Zonguldak Bülent Ecevit Üniversitesi Biyoistatistik Anabilim Dalı Öğretim Üyesi Çağatay BÜYÜKUYSAL’a teşekkür ederiz.

\section{KAYNAKLAR}

1. Ersoy R, Çakır B. Obezite. Turkish Med J 2007;1:107-116.

2. Öztürk A, Aktürk S. İlköğretim öğrencilerinde obezite prevalansı ve ilişkili risk faktörleri. Taf Prev Med Bull 2011;10(1):53-60.

3. Kaya H, Özçelik O. Vücut bileşimlerinin değerlendirilmesinde vücut kitle indeksi ve biyoelektrik impedans analiz metodlarının etkinliğinin yaş ve cinsiyete göre karşılaştırilmasi. FÜ Sağ Bil Tip Derg 2009;23(1):1-5.

4. Yıldırım İ, Yıldırım Y, Işıı Ö, Karagöz Ş, Ersöz Y, Doğan İ. Üniversite öğrencilerinde farklı ölçüm yöntemlerine göre obezite prevelansı. İnönü Üniversitesi Beden Eğitimi ve Spor Bilimleri Dergisi 2017;4(2):20-33. 
5. Kayihan G, Ersöz G. 15-18 yaş grubu adolesanlarda obezite tanısında ve vücut yağ yüzdesinin belirlenmesinde kullanılan farklı yöntemlerin karşılaştırılması. Turkiye Klin J Sport 2009;1(2):107-116.

6. Çetin İ, Muhtaroğlu S, Yılmaz B, Kurtoğlu S. Evaluation of segmental body composition by gender in obese children using bioelectric impedance analysis method. Dicle Med J 2015;42(4):449-454.

7. Üçok K, Mollaoğlu H, Akgün L, Genç A. İki farklı yöntemle ölçülen istirahat metabolizma hızlarının karşılaştırılması. Genel Tip Derg 2008;18(3):117-120.

8. Şanlier N. Gençlerde biyokimyasal antropometrik ölçümler, vücut bileşimi, beslenme ve fiziksel aktivite durumlarının değerlendirilmesi. GÜ Gazi Eğitim Fakültesi Dergisi, Cilt 25, Say1 3 (2005) 47-73

9. Kadioglu M, Ergün A. Üniversite Öğrencilerinin Yeme Tutumu, Öz-Etkililik ve Etkileyen Faktörler. Marmara Üniversitesi Sağlık Bilimleri Enstitüsü Dergisi Cilt: 5, Sayı: 2, 2015 / Journal of Marmara University Institute of Health Sciences Volume: 5, Number: 2, 2015

10. Altın M. Üniversite Öğrencilerinin Beslenme Alışkanlıkları ve Obezite İlişkisi. Sportif Bakış: Spor ve Eğitim Bilimleri Dergisi, 2 (2), 87-96, 2015

11. Turan T, Ceylan SS, Çetinkaya B, Altundağ S. Meslek lisesi öğrencilerinin obesite sıklığının ve beslenme alışkanlıklarının incelenmesi. Taf Prev Med Bull 2009;8(1):5-12.
12. Savc1 S, Öztürk M, Arikan H, Ince Dİ, Tokgözoğlu L. Üniversite öğrencilerinin fiziksel aktivite düzeyleri. Turk Kardiyol Dern Ars 2006;34(3):166-172.

13. Çağdaş Ayvaz DN, Nişancı Kılınç F, Paç FA, Çakal E. Anthropometric measurements and body composition analysis of obese adolescents with and without metabolic syndrome. Turk J Med Sci 2011;41(2):267-274.

14. Tam AA, Çakır B. Approach of obesity in primary health care. Ankara Med J 2012;12(1):37-41.

15. Aktas D, Ozturk F, Kapan Y. Determination of the obesity prevalence and affecting risk factors, of eating habits among adolescents. Taf Prev Med Bull 2016;14(5):406.

16. Temur HB. An assesment on the basal metabolic rate according to chosen variables. J Hum Sci 2018;15(4):1914.

17. Ergin Z. Tuzun üretim teknolojisi ve insan sağllğındaki yeri. Bilimsel Madencilik Dergisi 1988;27(1):9-30.

18. Genctoy G. Tuz ve böbrek yetmezliği. Turkiye Klin J NephrolSpecial Top 2017;10(2):73-83.

19. Mesci E. Obesity and fragility fractures. Medeni Med J 2016;31(1):58-64.

20. Öz B, Karataş A, Akar ZA, Koca SS. Obezite ve kas-iskelet sistemi. Frrat Med J 2018;23:42-47.

21. Asomaning K, Bertone-Johnson ER, Nasca PC, Hooven F, Pekow PS. The association between body mass index and osteoporosis in patients referred for a bone mineral density examination. J Women's Heal 2006;15(9):1028-1034. 
